\title{
Ultrases ve Kaplama Ön İşlemlerinin Infrared Kurutulmuş Ayva Numunelerinde Kuruma Verimi ve Kalite Parametreleri Üzerine Etkisi
}

\author{
Tansu Y1ldırım ${ }^{1 *}$, Oya Sipahioğlu² \\ 1*Erciyes Üniversitesi, Mühendislik Fakültesi, Gıda Mühendisliği Bölümü, Kayseri, Türkiye, (ORCID: 0000-0001-5624-6948), tansuyildirim01@hotmail.com \\ ${ }^{2}$ Erciyes Üniversitesi, Mühendislik Fakültesi, Gıda Mühendisliği Bölümü, Kayseri, Türkiye (ORCID: 0000-0003-2932-6007), oyasipahioglu@gmail.com
}

(1st International Conference on Applied Engineering and Natural Sciences ICAENS 2021, November 1-3, 2021)

(DOI: 10.31590/ejosat.1010668)

ATIF/REFERENCE: Yıldırım, T. \& Sipahioğlu, O.,., (2021). Ultrases ve Kaplama Ön İşlemlerinin Infrared Kurutulmuş Ayva Numunelerinde Kuruma Verimi ve Kalite Parametreleri Üzerine Etkisi. Avrupa Bilim ve Teknoloji Dergisi, (28), 819-825.

\section{Öz}

$\mathrm{Bu}$ çalışmanın amacı ayva işlemede infrared kurutma sisteminde ön işlem olarak ultrases ile düşük metoksil pektin ve sodyum aljinat kaplama uygulamalarının kurutulmuş ayvaların fiziko-kimyasal kalitesi üzerine etkisinin belirlenmesidir. Kurutma öncesi ayva örnekleri $(2 \mathrm{~cm} \mathrm{x} 2 \mathrm{~cm} \times 0.5 \mathrm{~cm}) 70^{\circ} \mathrm{C}^{\prime}$ de etüvde 24 saat ve $105^{\circ} \mathrm{C}^{\prime}$ de infrared kurutma cihazında kurutulmuştur. Beş farklı yöntem ile kurutulan ayvaların fizikokimyasal özellikleri (nem, kül, titrasyon asitliği, suda çözünebilir kuru madde, yağ ve protein) tespit edilmiş; $\mathrm{pH}$, su aktivitesi, çekme oranı, rehidrasyon kapasitesi, renk, toplam fenolik, toplam flavonoid içerikleri, antioksidan kapasiteleri (TEAC ve DPPH) ve tekstürel özellikleri karş̧laştırılmıştır. Düşük metoksil pektin ve sodyum aljinat kaplama işlemi örneklerin fenolik ve antioksidatif bileşiklerin kaybını azaltmıştır. Infrared kurutma işlemi ayvaların fenolik, antioksidatif ve flavanoid bileşiklerini koruduğu tespit edilmiştir. Ultrases ön işlemi uygulanıp infrared kurutulan örneklerin fenolik, antioksidatif ve flavanoid bileşiklerin miktarında bir artış gözlenmiştir. Infrared kurutma işleminde L değerinde artış meydana gelmiştir. L değerinde görülen artış esmerleşme reaksiyonlarının azaldığının göstergesidir. Düşük metoksil pektin kaplama uygulanıp infrared kurutulan örneklerde $L$ ve $b^{*}$ değerinde artış, a* değerinde azalış tespit edilmiştir. Ultrases ve kaplama ön işlemleri uygulanıp infrared kurutulan ayvaların renginin korunduğu tespit edilmiştir. Ayva örneklerinin sertlik özellikleri tekstür analizi ile incelenmiştir. Etüv kurutmada görülen kurutma süresi artışının, ürün sertlik değeri üzerinde artırıcı etkisi olduğu tespit edilmiştir. Çalışmalar infrared sistemde kurutma işleminin ayva örneklerinin aşırı sertleşmesini önleyen bir yöntem olduğunu göstermiştir. Sonuç olarak, ayva meyvesinin antioksidan aktivite, toplam fenolik bileşik, toplam flavanoid ve tekstürel özelliklerini korumak için sodyum aljinat ve düşük metoksil pektin kaplamaların yenilebilir kaplamalar olarak kullanılabileceği, ultrases ve kaplama ön işlemlerinin infrared kurutulmuş ayva örneklerinde kuruma verimini ve kalitesini artırmada etkin bir yöntem olduğunu göstermiştir.

\section{The Effect of Ultrasound and Coating Pretreatments on Drying Yield and Quality Parameters of Infrared Dried Quince Samples}

This study aims to determine the effects of ultrasound and low methoxy pectin and sodium alginate coating applications on the physicochemical quality of dried quince in infrared drying systems in quince processing. Before drying, quince samples $(2 \mathrm{~cm} x 2 \mathrm{~cm}$ $\mathrm{x} 0.5 \mathrm{~cm}$ ) were dried in an oven at $70{ }^{\circ} \mathrm{C}$ for 24 hours and at $105^{\circ} \mathrm{C}$ in an infrared drying device. The physicochemical properties (moisture, ash, titration acidity, water-soluble dry matter, oil, and protein) of quinces dried by five different methods were determined; $\mathrm{pH}$, water activity, shrinkage ratio, rehydration capacity, color, total phenolic, total flavonoid contents, antioxidant capacities (TEAC and DPPH) and textural properties were compared.

*Sorumlu Yazar: tansuyildirim01@hotmail.com 
The low methoxyl pectin and sodium alginate coating process reduced the loss of phenolic and antioxidative compounds of the samples. It has been determined that the infrared drying process preserves phenolic, antioxidative, and flavonoid compounds of quinces. An increase in the amount of phenolic, antioxidative, and flavonoid compounds was observed in the ultrasound pretreatment and infrared dried samples. The $\mathrm{L}$ value increased in the infrared drying process. The increase in $\mathrm{L}$ value is an indication of a decrease in browning reactions. An increase in $\mathrm{L}$ and $\mathrm{b}^{*}$ values and a decrease in $\mathrm{a}^{*}$ values were detected in the samples that were applied low methoxyl pectin coating and infrared dried. It has been determined that the color of the quince, which is infrared dried after applying ultrasound and coating pre-treatments, is preserved. The hardness properties of quince samples were investigated by texture analysis. It has been determined that the increase in drying time in oven drying has an increasing effect on the product hardness value. Studies have shown that drying in the infrared system is a method that prevents excessive hardening of quince samples. As a result, it has been shown that sodium alginate and low methoxyl pectin coatings can be used as edible coatings to preserve the antioxidant activity, total phenolic compound, total flavonoid and textural properties of quince fruit, and ultrasound and coating pretreatment is an effective method to increase the drying yield and quality of infrared dried quince samples.

Keywords: Quince, Coating, Ultrasound, Infrared Drying, Antioxidant Activity.

\section{Giriş}

İnsanların günlük ihtiyaçlarının giderilmesinde beslenmenin önemi oldukça yüksektir. Meyve ve sebzeler yapılarındaki yüksek nem içeriğiyle kimyasal ve mikrobiyolojik açıdan sıkça bozulabilen gida bileşenleridir [1]. Günümüzde geleneksel kurutma olarak bilinen güneşte kurutma işleminin çok sağlıklı olmaması, gıdaya havadan ve topraktan bazı mikroorganizmaların buluşması ve küf gelişiminin önlenememesi gibi sebepler farklı kurutma yöntemlerinin bulunmasına ihtiyaç doğurmuştur. Ayva (Cydonia oblonga), Rosaceae familyasından olup Cydonia cinsidir. Ayva asitliği yüksek, yumuşak çekirdekli ancak sert formlu, kabukları tüylü bir meyvedir. Ayvanın lifli yapısı sindirimin kolaylaşmasını sağlar. Pektin E440 koduna sahip gıda katkı maddesidir. Pektin meyve ve sebzelerde yüksek oranda bulunan bir polisakkarittir. Pektin molekülü D-galakturonik asit monomerlerinin $\alpha-1,4$ bağı ile bağlanmasıyla oluşmaktadır. Esterleşme derecesine göre pektinler düşük metoksilli ve yüksek metoksilli pektin olmak üzere ikiye ayrılmaktadır. Düşük metoksilli pektinlerin esterleşme derecesi \%50 ve \%50'nin altında, yüksek metoksilli pektinlerin esterleşme derecesi \%50'nin üstünde olmaktadır. Pektinin kullanım alanları; gıda, ilaç, tekstil ürünlerinde jel yapıcı olarak, stabilizan, emülsifiyan, yenilebilir filmler, köpükler, plastikleştiriciler, kâğıt sübstitüentler yer almaktadır. Ayvada pektin yüksek oranda bulunmaktadır.

Aljinatlar kahverengi deniz yosunlarının (Phaeophyceae) hücre duvarlarından elde edilen polisakkaritlerdir. Aljinatlar $\beta$-Dmannuronik asit (M) ve $\alpha$-L-glukuronik asidin (G) 1-4 glikozidik bağlarla bağlanan dallanmamış yapılardır. Sodyum aljinat ise geri dönüştürülebilen, biyo-uyumlu bir materyaldir. Gida endüstrisinde sodyum aljinat; jelleştirici, emülsiyon sabitleyici, viskozite ve kıvam artırıcı olarak içecekler, soslar, çorbalar ve tatlılarda kullanılmaktadır. Sodyum aljinatın farkedilebilen aroması yoktur, vücutta sindirilemez ve jelleşme hızı yüksektir. Sodyum aljinatın oluşturduğu jel geriye dönüştürülemez ve ısıya dayanıklıdır. Sodyum aljinat doğal bir selülozdur ve kanda yăg asitlerinin, safra tuzlarının, şekerin emilimini düşürmektedir. Aynı zamanda serum kolesterolü azaltıcı etkisi vardır. Sodyum aljinat stronsiyum (Sr), kadmiyum $(\mathrm{Cd})$ ve kurşun $(\mathrm{Pb})$ gibi ağır metallerin vücutta birikmesini önleyen bir katk1 maddesidir. Vücutta zararlı etkileri olan radyoaktif toksinleri bağlayan iyi bir şelat ajanıdır [2]. Kaplama materyalleri yüksek işlem sıcaklığında uygulandığında, hücre çökmesini azaltarak daha yüksek su difüzyonu sağlamaktadır.

Ultrases enerjisi, nesnelerin titreşiminden oluşur ve ortam içinde bir yerden başka bir yere sıkışma ve genleşme hareketiyle ilerleyen mekanik bir enerji formudur [3]. G1daya uygulanan 1s1l işlemler ultrases ile kombinasyon halinde kullanıldıklarında olumsuz etkiler nispeten azalabilmektedir. Ultrases teknolojisi çevreye dost, güvenli, düşük maliyetli bir teknolojidir. Infrared 1sitma teknolojisi $0,5-100 \mu \mathrm{m}$ dalga boyunda uygulanan elektomanyetik spektruma sahiptir. Ultrases ön işlemi hücre zarını parçalayarak suyun difüzyonunu artırmaktadır. Infrared kurutma, sıcak hava ile kurutma yöntemine kıyasla ürünün yapısını bozmadan kurutma sağlar. Infared kurutma sisteminin kurutma süresinin kısa olması, yüksek ısıl verimlilik, homojen 1sıtma sağlaması, kalite kayıplarının ve gıda bileşenlerinin besinsel kayıplarını kısaltması, basit ekipman sistemi, zaman ve enerji tasarrufu sağlaması yönünden avantajları infrared kurutmanın tercih edilmesini sağlamaktadır [4].

\section{Materyal ve Metot}

\subsection{Ayva Numunelerine Ultrases Ön İşlemi Uygulaması}

Ayvalar $250 \mathrm{~mL}$ 'lik plastik torbalar içerisine katı/çözelti oranı 1:4 olmak üzere yerleştirilmiş ve işlem $40{ }^{\circ} \mathrm{C}$ sicaklıkta su banyosu kullanılarak yürütülmüştür. İşlem süresi $40 \mathrm{dk}$ olarak belirlenmiştir. Ön işlem sonrasında örneklerin yüzeyindeki su kaba filtre kâğıdı ile kurulandıktan sonra tartım yapılmıştır.

\subsection{Ayva Numunelerine Kaplama İşlemi Uygulaması}

Ultrases ön işlemi uygulanan ayva numuneleri $5 \mathrm{dk}$ boyunca $\% 1$ sodyum aljinat (SA) ve $\% 2$ düşük metoksil pektin (LMP) içine daldırılmıştır. Daha sonra SA kaplı ayva numuneleri $\% 1$ kalsiyum klorür $\left(\mathrm{CaCl}_{2}\right)$ ve LMP kaplı ayva numuneleri $\% 2$ kalsiyum klorür $\left(\mathrm{CaCl}_{2}\right)$ çözeltisi içinde $30 \mathrm{dk}$ süreyle bekletilmiştir. Numuneler, $\mathrm{CaCl}_{2}$ çözeltisinden çıkarıldıktan sonra kalsiyum ve kaplama malzemesi arasında çapraz bağlanmanın daha sıkı olması için oda sıcaklığında $5 \mathrm{dk}$ bekletilmiştir. Son olarak, numuneler $\mathrm{CaCl}_{2}$ kalıntısı kalmaması için su ile yıkandıktan sonra suyun daha iyi süzülmesi için filtre kağıdından geçirilmiş ve filtre kağıdı üzerinde kalan ayva numuneleriyle gerekli işlemler yapılmıştır [5].

\subsubsection{Nem Tayini}

Ayva numunelerinde nem miktarı AACC 44-19 metoduna göre belirlenmiştir. Petri kaplarına $5,0 \pm 0,1 \mathrm{~g} 2 \times 2 \times 0,5 \mathrm{~cm}$ boyutundaki ayva örnekleri tartılmış ve $75 \pm 1^{\circ} \mathrm{C}$ 'de 24 sa boyunca işlem devam etmiştir [6]. 


\subsubsection{Kül Tayini}

Kül miktarı ayva numunelerinde AACC 08-01 metodu ile belirlenmiştir. Örnekler $550-600{ }^{\circ} \mathrm{C}$ ' de gri-beyaz kül rengi oluşuncaya kadar yakma işlemi yapılmıştır [7].

\subsection{3. pH ve Titrasyon Asitliği Tayini}

Ayva örneklerinden örneklerden $5 \mathrm{~g}$ alınıp üzerine $100 \mathrm{~mL}$ deiyonize su ilave edilerek homojenize edilmiştir. Daha sonra elde edilen karışım filtre kâğıdı ile süzülmüştür. Elde edilen örneğin pH değeri, pH metre elektrodu kullanılarak belirlenmiştir [8]. Titrasyon asitliği tayini için $1 \mathrm{~g}$ ayva numunesi tartılıp saf su ile $50 \mathrm{~mL}$ ' ye seyreltilmiştir. Homojenize edilip seyreltilen örnekten $20 \mathrm{~mL}$ alınarak birkaç damla fenolftalein indikatörü eklendikten sonra, kalıcı pembe bir renk elde edilene kadar $0,1 \mathrm{~N} \mathrm{NaOH}$ ile titre edilmiştir [9].

\subsubsection{Su Aktivitesi ( $\left.a_{w}\right)$ Tayini}

Örnekler ölçüm cihazının kaplarına kabın 3/4'ünü dolduracak miktarda konulmuş ve oda sicaklığında $\left(25 \pm 0.2^{\circ} \mathrm{C}\right)$ denge nem değerine ulaşana kadar bekletilmiş, $\mathrm{a}_{\mathrm{w}}$ değeri dijital göstergeden kaydedilmiştir [7].

\subsubsection{Suda Çözünebilir Kuru Madde Tayini}

Taze ve kurutulmuş ayva örnekleri homojenizatörden geçirildikten sonra numunelerin suda çözünebilir kuru madde miktarı (SÇKM) dijital refraktometre ile belirlenmiştir.

\subsection{6. Çözü̈cü Ektraksiyonu ile Yağ Miktarı Tayini}

Ayva numunelerinde yağ miktarı Soxhlet yöntemi kullanılarak AACC 30-25 metodu ile belirlenmiştir. Örneklerden 3'er g tartılarak kartuşlara yerleştirilmiştir. Yağ miktarı tayininde çözücü olarak yaklaşık 1.5 sifon yapacak miktarda kaynama noktası $40-60{ }^{\circ} \mathrm{C}$ olan petrol eteri çözücüsü ile 6 sa Soxhlet ekstraksiyonu yapılmıştır. Ekstraksiyon süresi sonunda kalan çözücü döner buharlaştırıcıda uzaklaştırılmıştır [10].

\subsubsection{Protein Tayini}

Ayva numunesinin protein içeriği, Kjeldahl yöntemine dayanan AOAC 2000'e göre \%azot miktarı ölçülerek belirlenmiştir. $1 \mathrm{~g}$ örnek üzerine $25 \mathrm{ml} \mathrm{H}_{2} \mathrm{SO}_{4}$ ve 1 adet Kjehdahl tableti konulup yakma işlemi yapılmıştır. Kjheldahl balonuna ise yakılan örnek ve $125 \mathrm{~mL} \% 40$ 'lı $\mathrm{NaOH}$ çözeltisi ilave edilerek distilasyon yapılmıştır. Daha sonra $50 \mathrm{~mL}$ borik asit konulup $\mathrm{HCl}$ ile titrasyon yapılmıştır. Titrasyondan sonra \%Protein miktarı hesaplanmıştır.

\subsubsection{Rehidrasyon Kapasitesi}

Ayva örneklerinden $1 \mathrm{~g}$ alınmış ve $80{ }^{\circ} \mathrm{C}$ sıcaklıktaki distile su içerisinde $15 \mathrm{dk}$ bekletilmiştir. Daha sonra numuneler süzülmüş ve işlem sonrası ağırlık artışı ölçülmüştür.

\subsection{9. Çekme Orant}

Ayva numunelerinin çekme oranı, kurutulmuş numunelerin köşegen uzunluğu ve kurutma öncesi taze ayva numunelerinin köşegen uzunluğuna oranıdır. Her bir ayva numunesinin çapı, 0,01 mm duyarlılıkta dijital bir kumpas kullanılarak ölçülmüştür.

\subsubsection{Toplam Fenolik Madde Analizi}

Toplam fenolik madde tayininde Folin Ciocalteu yöntemi kullanılmıştır. Denemeler sonunda seyreltilen ekstraktan deney tüplerine $0,4 \mathrm{~mL}$ alınmış ve tüplerin üzerine $2 \mathrm{ml}$ saf su ile $10 \mathrm{~kat}$ seyreltilen Folin \& Ciocalteu ayracı eklenerek çalkalanmıştır. 5 dakika bekletildikten sonra 1,6 mL \% 7,5'luk sodyum karbonat çözeltisi eklenmiş ve balon içeriği damıtık su ile balon çizgisi işaretine tamamlanmıştır. Deney tüpleri oda sıcaklığında ve karanlık ortamda 1 sa bekletildikten sonra spektrofotometrede (UV-spektrofotometre UV-1800, Shimadzu, Japonya) $765 \mathrm{~nm}$ dalga boyunda kör çözeltiye karşı okuma yapılmıştır.

\subsubsection{Toplam Flavanoid Miktarı Tayini}

Ayva örneklerinden hazırlanan ekstraktlar belli oranda seyreltilip ekstraktlardan $1 \mathrm{~mL}$ alınıp deney tüplerine alınmıştır. Üzerine \%5'lik hazırlanan $\mathrm{NaNO}_{2}$ çözeltisinden $0,3 \mathrm{~mL}$ eklenmiş ve $5 \mathrm{dk}$ bekletilmiştir. Süre sonunda \%10'luk hazırlanan $\mathrm{ALC}_{3}$ çözeltisinden $0,3 \mathrm{~mL}$ eklenerek $1 \mathrm{dk}$ bekletilmiştir. Süre sonunda tüplere $2 \mathrm{~mL} 1 \mathrm{M} \mathrm{NaOH}$ çözeltisi eklenmiş ve toplam hacim 10 mL olacak şekilde saf su ile tamamlanmıştır. Kör çözelti için örnek yerine aynı miktarda saf su eklenerek örnek için uygulanan işlemler yapılmıştır. Spektrofotometrede kalibrasyon eğrilerinin oluşturulması için belli konsantrasyonlarda kuersetin standart çözeltileri hazırlanmış ve tüplere $1 \mathrm{~mL}$ eklenmiştir. Hazırlanan çözeltilerin absorbans değerleri spektrofotometrede $510 \mathrm{~nm}$ 'de okunmuştur.

\subsubsection{DPPH Serbest Radikal Yakalama Aktivitesi Tayini}

Ayva numunelerin antioksidan aktivite tayini DPPH yöntemi kullanılarak belirlenmiştir. Toplam fenolik madde tayininde belirlenen yöntemle örnek ekstraksiyonu yapılmıştır. Hazırlanan ekstrakt seyreltme işlemi yapılmadan analizde direkt kullanılmıştır. Analizde hazırlanan ekstraktlardan tüplere $30 \mu \mathrm{L}$ konulmuştur. Üzerine $270 \mu \mathrm{L} \% 80$ 'lik metanol çözeltisi ve 270 $\mu \mathrm{L}$ DPPH çözeltisinden eklenmiştir. Hazırlanan çözelti karanlıkta oda sicaklığında 1 sa bekletilmiştir. Süre sonunda spektrofotometrede $520 \mathrm{~nm}$ dalga boyunda saf metanole karşı okuma yapılmıştır.

\subsubsection{TEAC (ABTS) ile Antioksidan Kapasite Analizi}

Antioksidan kapasitenin belirlenmesinde ABTS (2,2'-azinobis (3-etilbenzothiazolin 6-sulfonik asit) radikali kullanılmıştır. ABTS radikali hazırlanırken, 0,0384 g ABTS radikali tartılmıştır, üzerine $0,01225 \mathrm{M}$ hazırlanan potasyum persülfat çözeltisinden (PBS) $2 \mathrm{~mL}$ eklenmiş ve saf su ile $10 \mathrm{~mL}$ ye tamamlanmıştır. Hazırlanan bu çözelti analizde kullanılmadan önce 12-16 sa karanlıkta oda sıcaklığında bekletilmiştir. Tuzlu fosfat tamponu (PBS) hazırlanırken $19 \mathrm{~mL} \mathrm{0,2} \mathrm{M} \mathrm{NaH}_{2} \mathrm{PO}_{4}$ ve $81 \mathrm{ml} \mathrm{0,2} \mathrm{\textrm {M }}$ $\mathrm{Na}_{2} \mathrm{HPO}_{4}$ çözeltileri tartılarak $1000 \mathrm{~mL}$ lik balona konulmuştur. Üzerine 8,77 g NaCl katısı eklenerek saf su eklenmiş ve pH 7,4 olacak şekilde ayarlanmıştır. $\mathrm{pH} \mathrm{7,4}{ }^{\circ} \mathrm{e}$ ayarlandıktan sonra balon hacmi $1000 \mathrm{~mL}$ olacak şekilde saf su ile tamamlanmıştır. Analiz esnasında ABTS radikali spektrofotometrede $734 \mathrm{~nm}$ dalga boyunda fosfat tamponu (PBS) ile seyreltilerek 0,698-0,720 absorbans değerini verecek şekilde ayarlanmıştır. Örnekler 20, 40, 60 ve $80 \mu \mathrm{L}$ ye PBS ile seyreltilmiştir. Seyreltilen örneklerden $20,40,60$ ve $80 \mu \mathrm{L}$ alınarak $2 \mathrm{~mL}$ hacmine sahip plastik küvetlere konulmuştur. Üzerine $2 \mathrm{~mL}$ ABTS radikali eklenmiş ve $6 \mathrm{dk}$ bekletilmiştir. Süre sonunda örneklerin spektrofotometrede absorbans değerleri okunmuştur.

\subsubsection{Renk Analizi}

Ayva örneklerinde üç boyutlu renk ölçümü esasına dayanan minolta kolorimetre (Chroma Meter, CR-500, Minolta, Japonya) cihazı ile ölçüm yapılmıştır. Renk ölçümü numunenin kuruma öncesinde ve kuruma sonrasında 5 farklı ayva numunesinde 
Hunter renk sistemine göre (L, a, b) yapılmıştır. Örneklerin cihaz ekranından okunan Hunter L (parlaklık), a (kırmızılık-yeşillik) ve b (sarılık-mavilik) değerleri kaydedilmiştir.

\subsubsection{Tekstür Profili Analizi (TPA)}

Ayva örneklerinin tekstür profil analizi (TPA), Texture Analyser cihazı (TAXT2 Plus, Stable Micro Systems, İngiltere) ile belirlenmiştir. Seçilen numuneler cihaz platformunun

\subsubsection{6. İstatiksel Analiz}

Yapılan uygulamaların ayva örneklerine etkisinin incelenmesi amacıyla gerçekleştirilen analizler sonucunda elde edilen veriler merkezine yatay olarak yerleştirilmiş ve silindirik paslanmaz çelik prob yardımıyla baskı uygulanmıştır. Test parametreleri; test öncesi hız $2.00 \mathrm{~mm} / \mathrm{s}$, test hız1 $2 \mathrm{~mm} / \mathrm{s}$, test sonrası hiz $2.00 \mathrm{~mm} / \mathrm{s}$, mesafe $5 \mathrm{~mm}$, süre $5 \mathrm{~s}$ ve başlangıç kuvveti $5 \mathrm{~g}$ olarak belirlenmiştir. Ayva örneklerinin arka arkaya iki kez sıkıştırılmasıyla analiz gerçekleştirilmiştir. Analizde kullanılan tektür cihazının yazılımı (Texture Exponent 32) kullanılarak ayva numunelerinin sertlik (hardness) parametreleri TPA eğrisinden hesaplanmıştır [11.

Minitab 18.0 programı kullanılarak istatistiksel olarak değerlendirilmiştir. Değerlerin ortalamasının kıyaslanmasında tek faktör varyans analizi (ANOVA), gruplar arasındaki farklılıkların belirlenmesinde ise Tukey çoklu karşılaştırma testi kullanılmıştır. Veriler \%95 güven aralığında test edilmiştir.

Tablo 1.Deneysel Tasarım

\begin{tabular}{ccccc}
\hline Uygulanan İşlemler & Ön İşlem & $\begin{array}{c}\text { Kurutma } \\
\text { Sistemi }\end{array}$ & Sicaklık $\left({ }^{\circ} \mathbf{C}\right)$ & Süre \\
\hline $\mathbf{E}$ & - & Etüv & 75 & 24 saat \\
\hline IR & - & Infrared & 105 & Sabit ağıllığa ulaşıncaya kadar \\
\hline US+IR & $35 \mathrm{kHz} / 40$ dk ultrases & Infrared & 105 & Sabit ağırlığa ulaşıncaya kadar \\
\hline US+LMP+IR & $\begin{array}{c}35 \mathrm{kHz} / 40 \text { dk ultrases ve } \% 2 \\
\text { LMP kaplama }\end{array}$ & Infrared & 105 & Sabit ağırlı̆̆a ulaşıncaya kadar \\
\hline US+SA+IR & $\begin{array}{c}35 \mathrm{kHz} / 40 \text { dk ultrases ve } \% 1 \\
\text { SA kaplama }\end{array}$ & Infrared & 105 & Sabit ağırlığa ulaşıncaya kadar \\
\hline
\end{tabular}

[E: Etüv kurutma, IR: Ön işlemsiz infrared kurutma, US: Ultrases, LMP: Düşük metoksil pektin kaplama, SA: Sodyum aljinat kaplama]

\section{Araştırma Sonuçları ve Tartışma}

Fenolik bileşikler meyve ve sebzelerde genellikle çok az miktarda bulunan bileşiklerdir. Fenolik bileşikler, acı ve buruk tadın oluşmasında rol alırken bir kısmı meyve ve sebzelerin kırmızı-mavi, sarı, sarı-esmer renginin oluşmasında rol oynarlar. Ultrases teknolojisi ön işlem olarak uygulandığı durumlarda polifenollerin, polisakkartlerin, yağların, antosiyanidinlerin ve fonksiyonel bileşiklerin ekstraksiyonunu artırıcı etkisi bulunmaktadır [12, 13]. Gidalarda kullanılan yenilebilir kaplamalar, gıdanın doku yumuşamasına ve esmerleşme reaksiyonlarına karşı enzimatik oksidasyonu geciktirerek koruma Tablo 3. 1 Bulgular sağlamaktadır. Yenilebilir kaplamalar renk bileşenlerinin kaybını önleyici özellik gösterirler. Enzimatik aktivitelerin kontrol edilmesini sağlarlar.

Yenilebilir kaplama, nem ve gaz bariyeri özellikleri sağlayarak gıda kalitesini korumaya ve raf ömrünü iyileştirmeye yönelik potansiyel bir alternatiftir. Kaplama, genellikle su uzaklaştırmanın önündeki bir engel olarak düşünülebilir. Bununla birlikte, yüksek işlem sıcaklığında kaplama, hücre çökmesinin azaltılmasına yardımcı olabilmekte ve daha yüksek su difüzyonu sağlamaktadır. Aynı zamanda kaplama materyalleri hücre zarının aşırı yumuşamasını önlemektir.

\begin{tabular}{|c|c|c|c|c|c|c|}
\hline Analizler & $\mathbf{T}$ & $\mathbf{E}$ & IR & US+IR & US+LMP+IR & $\mathrm{US}+\mathrm{SA}+\mathrm{IR}$ \\
\hline $\operatorname{Nem}(\%)$ & $86,48^{\mathrm{a}}$ & $10,38^{\mathrm{c}}$ & $16,52^{b}$ & $12,67^{\mathrm{c}}$ & $18,69^{\mathrm{b}}$ & $18,25^{\mathrm{b}}$ \\
\hline Su Aktivitesi (a $\left.a_{w}\right)$ & $0,24^{\mathrm{a}}$ & $0,22^{b}$ & $0,22^{b}$ & $0,21^{b}$ & $0,22^{b}$ & $0,22^{b}$ \\
\hline SÇKM (\%) & $0,21^{\mathrm{d}}$ & $1,30^{\mathrm{a}}$ & $1,35^{\mathrm{a}}$ & - & $0,98^{b}$ & $0,90^{\mathrm{c}}$ \\
\hline Kül (\%) & $0,02^{\mathrm{b}}$ & $0,02^{b}$ & - & - & $0,07^{\mathrm{a}}$ & $0,06^{\mathrm{a}}$ \\
\hline pH & $4,36^{\mathrm{a}}$ & $3,94^{\mathrm{b}}$ & - & - & $3,97^{\mathrm{b}}$ & $3,90^{\mathrm{c}}$ \\
\hline Titrasyon Asitliği (\%) & $0,015^{\mathrm{c}}$ & $0,070^{\mathrm{b}}$ & - & - & $0,013^{\mathrm{d}}$ & $0,125^{\mathrm{a}}$ \\
\hline Yağ (\%) & $0,04^{\mathrm{c}}$ & $0,15^{\mathrm{a}, \mathrm{b}}$ & - & - & $0,20^{\mathrm{a}}$ & $0,10^{\mathrm{b}, \mathrm{c}}$ \\
\hline Protein $(\%)$ & $0,01^{\mathrm{c}}$ & $0,02^{b}$ & - & - & $0,04^{\mathrm{a}}$ & $0,10^{\mathrm{a}}$ \\
\hline Rehidrasyon Oranı & - & $1,64^{\mathrm{c}}$ & $2,14^{b}$ & $2,26^{\mathrm{b}}$ & $2,54^{\mathrm{a}}$ & $2,19^{b}$ \\
\hline Çekme Oranı & - & $1,983^{\mathrm{a}}$ & $1,937^{\mathrm{a}, \mathrm{b}}$ & $1,779^{c}$ & $1,787^{\mathrm{b}, \mathrm{c}}$ & $1,970^{\mathrm{a}, \mathrm{b}}$ \\
\hline
\end{tabular}

Aynı sütundaki farklı küçük harflerle belirtilen değerler arasında istatiksel açıdan önemli ölçüde fark bulunmaktadır ( $p<0,05$ ).

[T: Taze ayva, E: Etüv kurutma, IR: Ön işlemsiz infrared kurutma, US: Ultrases, LMP: Düşük metoksil pektin kaplama, SA: Sodyum aljinat kaplama] 
Ayva örneklerinin nem değerlerinin belirlenmesinde etüv ve infrared kurutma işlemleri belirgin bir farka sebep olmuştur. Infrared kurutma işlemi ayvaların nem içeriğinin korunmasını sağlamaktadır. Ayva örneklerine kaplama materyali uygulaması suyun yapıda korunmasını sağlayarak ürünün nem kaybetmesini önleyen bir işlemdir.

Örneklerin infrared kurutulması üzerine sodyum aljinat ve düşük metoksil kaplama uygulamaları örneklerinin titrasyon asitliği ve $\mathrm{pH}$ değeri üzerine istatiksel olarak anlamlı bir farklılık oluşturmuştur $(p<0,05)$. Etüvde kurutma işleminin titrasyon asitliği ve $\mathrm{pH}$ değeri üzerine etkisi yok denecek kadar az olmuştur. Ayva örneklerinin kuruma sonrasında çekme oranları karşılaştırılaştırıldığında etüvde ve infrared kurutma sisteminde

Meyve ve sebzelerde yağ ve protein oranı genellikle düşüktür. Bulgular incelendiğinde yağ içeriği taze ayvada en düşük bulunurken kaplama işlemlerinde yağ içeriğinde istatiksel bir artış gözlenmiştir. Bunun sebebi infrared kurutma işleminden önce yapılan ultrases ön işleminden kaynaklanmaktadır. Ayvalar üzerine düşük metoksil pektin ve sodyum aljinat kaplama uygulaması yağ içeriğini etkilemiştir. Ayva örneklerinin protein kurutulan örnekler istatiksel olarak anlamlı bir farklılık oluşturmamıştır $(p<0,05)$. Çekme oranı üzerine sodyum aljinat ile düşük metoksil pektin kaplaması karşılaştırıldığında, tüm işleme koşulları altında sodyum aljinat ve düşük metoksil pektin kaplı numuneler arasında performans oranında önemli bir fark bulunmamıştır. Sodyum aljinat kaplama işlemi istatiksel açıdan bir artış göstermiştir. Örneklerin rehidrasyon oranlarının belirlenmesinde etüv ve infrared kurutma işlemleri belirgin bir farka sebep olmuştur. Çalışmada elde edilen veriler incelendiğinde ultrases uygulaması örneklerin rehidrasyon oranı değerinde artış meydana getirmiştir. Bunun nedeni ultrases uygulamasının hücre zarının parçalayarak suyun geri kazanımını artırmasından kaynaklanıyor olabilmektedir.

içeriği en yüksek ultrases ile birlikte sodyum aljinat kaplama uygulanıp infrared kurutma uygulanan ayvalarda gözlenmiştir. Bu işlemi ultrases ile birlikte düşük metoksil pektin kaplama uygulanıp infrared kurutulan işlem takip etmektedir. Burada ultrases ön işleminin etkisi olduğu söylenebilir. Etüvde kurutulan örneklerin protein içeriği taze ayvaya yakın bulunmuştur. Ultrases ön işlemi ayvaların hücre zarını parçalalayıp azotlu bileşiklerin tayin edilmesini kolaylaştırdığı söylenebilmektedir.

Tablo 3. 2 Bulgular

\begin{tabular}{|c|c|c|c|c|c|c|}
\hline Analizler & $\mathbf{T}$ & $\mathbf{E}$ & IR & $\mathbf{U S}+\mathbf{I R}$ & US+LMP+IR & $\mathbf{U S}+\mathbf{S A}+\mathbf{I R}$ \\
\hline $\begin{array}{c}\text { Toplam Fenolik Bileşik Miktarı } \\
\text { (mg GAE/g) }\end{array}$ & $2,04^{\mathrm{d}}$ & $2,28^{d}$ & $6,03^{a}$ & $3,57^{\mathrm{c}}$ & $4,50^{\mathrm{b}}$ & $3,64^{\mathrm{c}}$ \\
\hline $\begin{array}{c}\text { Toplam Flavanoid Miktarı (mg } \\
\mathrm{KE} / \mathrm{g})\end{array}$ & $0,12^{c}$ & $0,49^{\mathrm{b}, \mathrm{c}}$ & $1,21^{\mathrm{a}, \mathrm{b}}$ & $1,29^{\mathrm{a}}$ & $0,89^{\mathrm{a}, \mathrm{b}, \mathrm{c}}$ & $0,70^{\mathrm{a}, \mathrm{b}, \mathrm{c}}$ \\
\hline DPPH (mg GAE/g) & $22,03^{c}$ & $39,54^{\mathrm{b}}$ & $57,08^{\mathrm{a}}$ & $42,31^{b}$ & $53,38^{\mathrm{a}}$ & $36,52^{b}$ \\
\hline ABTS ( $\mu$ mol Trolox/mg) & $26,42^{b}$ & $20,20^{\mathrm{b}}$ & $35,74^{\mathrm{a}}$ & $21,30^{b}$ & $38,96^{\mathrm{a}}$ & $22,61^{b}$ \\
\hline$L^{*}$ & $55,36^{\mathrm{b}}$ & $39,86^{\mathrm{e}}$ & $52,27^{\mathrm{b}, \mathrm{c}}$ & $46,00^{d}$ & $61,83^{a}$ & $45,11^{\mathrm{c}, \mathrm{d}}$ \\
\hline$a^{*}$ & $3,15^{\mathrm{c}}$ & $15,06^{\mathrm{a}}$ & $17,39^{\mathrm{a}}$ & $14,32^{\mathrm{a}, \mathrm{b}}$ & $11,05^{b}$ & $16,45^{\mathrm{a}}$ \\
\hline $\mathbf{b}^{*}$ & $26,65^{\mathrm{b}}$ & $15,56^{\mathrm{d}}$ & $31,66^{\mathrm{a}}$ & $22,79^{c}$ & $27,27^{\mathrm{b}}$ & $25,16^{\mathrm{b}, \mathrm{c}}$ \\
\hline Sertlik (N) & $22,79^{a, b}$ & $34,19^{\mathrm{a}}$ & $31,08^{\mathrm{a}, \mathrm{b}}$ & $21,24^{\mathrm{b}}$ & $31,60^{\mathrm{a}, \mathrm{b}}$ & $32,63^{\mathrm{a}, \mathrm{b}}$ \\
\hline
\end{tabular}

Aynı sütundaki farklı küçük harflerle belirtilen değerler arasında istatiksel açıdan önemli ölçüde fark bulunmaktadır ( $p<0,05$ ).

[T: Taze ayva, E: Etüv kurutma, IR: Ön işlemsiz infrared kurutma, US: Ultrases, LMP: Düşük metoksil pektin kaplama, SA: Sodyum aljinat kaplama]

Çalışma bulguları incelendiğinde ön işlemlerin ve kurutma yöntemlerinin meydana getirdiği etki istatiksel olarak önemli bulunmuştur $(p<0.05)$. Örneklerin toplam fenolik bileşik miktarları 2,04 ile 6,03 mg GAE/ g aralığında bulunmuştur. Ultrases uygulaması örneklerin toplam fenolik bileşik değerinde

düşüş meydana getirmiştir. Düşük metoksil pektin ve sodyum aljinat kaplama örneklerin toplam fenolik bileşik miktarında belirgin bir farka sebep olmuştur. Fenolik bileşikler yüksek antioksidan kapasitesiye sahiptirler. Bu sebeple toplam fenolik bileşik miktarındaki artış antioksidan kapasitedeki artışla paralel olduğu söylenebilir.

Örneklerin toplam flavanoid miktarı 0,12-1,29 mg KE/g aralığında bulunmuştur. Ayva örnekleri üzerine yapılan işlemlerin flavanoid içeriğine olan etkisi incelendiğinde ultrases ön işleminin etkisi kontrol, etüvde kurutma ve kaplama işlemlerinden daha yüksek bulunmuştur. Bunun sebebi ultrases ön işleminin yapıda mikroskobik kanallar oluşturarak flavanoid bileşiklerinin ölçülmesine etkisi olduğu düşünülmektedir. Kaplama uygulamaları ise iç ve dış yapının gözenekliliğini azaltması sebebiyle flavanoid bileşiklerin belirlenmesini ultrases ön işlemine göre azaltmıştır. Düşük metoksil pektin ve sodyum aljinat kaplama uygulaması ayva örneklerinin toplam flavanoid miktarını istatistiksel açıdan etkilemediği tespit edilmiştir $(p<0,05)$. Ayva örnekleri sodyum aljinat ve düşük metoksil pektin ile kaplandığında kalın ve pürüzlü bir film tabakası oluşmakta ve ayvanın hücresel yapısına nüfuz etmektedir. Böylece kaplama materyallerinin örneklerin flavanoid bileşiklerinin belirlenmesini zorlaştırdığı tespit edilmiştir.

Örneklerin DPPH metodu kullanılarak antioksidan aktivitelerinin belirlenmesinde etüv ve infrared kurutma işlemleri belirgin bir farka sebep olmuştur. Ultrases uygulaması örneklerin DPPH değerinde artış meydana getirmiştir. Ayvaların kurutulmasında düşük metoksil pektin ve sodyum aljinat kaplama malzemesi infrared kurutma işleminde ayvalar üzerine farklı bir etki oluşturmuştur. ABTS ve DPPH yöntemleri ile belirlenen antioksidan aktivite değerleri birbirine paralellik göstermiştir. 
DPPH ve ABTS yöntemine göre belirlenen antioksidan aktivite değerlerine göre etüvde kurutma işlemi ayvaların antioksidatif içeriğinde bir düşüşe neden olduğu gözlenmiştir. Ayva ürünlerinde kaplama materyallerinin kullanımı antioksidan ve fenolik bileşik özelliklerinde bir gelişme sağlamıştır.

Etüv kurutmada istatiksel olarak görülen $L^{*}$ ve $b^{*}$ değerindeki azalış, $\mathrm{a}^{*}$ değerindeki artış Maillard reaksiyonunun gerçekleşmiş olabileceğinin belirtisidir. L değerinin düşük olması rengin daha koyu olduğunun göstergesidir. Düşük metoksil pektin kaplama işlemi ayvalarda Maillard reaksiyonuna neden olan PPO (polifenol oksidaz) enziminin aktivitesinin azalmasının, polifenollerin, karotenoidlerin ve $\mathrm{C}$ vitamininin oksidasyonunu baskılamada pektin kaplamaların etkili olduğunun göstergesidir. Farklı kurutma yöntemlerinin, ayva örneklerinin a* değerini istatistiksel açıdan etkilemediği fakat farklı kaplama malzemesi kullanımının $\mathrm{a}^{*}$ değerini istatistiksel açıdan etkilediği tespit edilmiştir $(p<0.05)$. Farklı kaplama malzemesi kullanımının, $b^{*}$ değerini istatistiksel açıdan etkilemediği fakat farklı kurutma yöntemlerinin $b^{*}$ değerini istatistiksel açıdan etkilediği tespit

\section{Sonuç}

$\mathrm{Bu}$ çalışma kapsamında endüstriyel sistemde kullanılmaya devam eden geleneksel kurutma metodlarına alternatif olarak yeni teknolojik uygulamaların kullanılması amaçlanmıştır. Sonuç olarak meyvelerin kurutulması üzerine infrared kurutma sisteminin geleneksel yöntemlere kıyasla ürün kalitesini artırdığ gözlenmiştir. Infrared teknolojisi, meyve ve sebze işlemede kullanılabilecek yüksek kapasiteli bir yöntemdir.

Kurutma yöntemleri ve uygulanan ultrases ön işlemleri örneklerin nem miktarını etkilemiştir. Meyvelerde sodyum aljinat kullanımı ısısal stabilite sağladığı gibi su salmayı önleme etkisi olduğu görülmektedir. Ultrases ön işlemi ise üründe suyun difüzyonunu artırarak nem miktarını etkilemiştir. Ultrases ön işlemi ile oluşan kavitasyon sebebiyle ayva örneklerinin bağıl nemi düşmüştür. $\mathrm{Bu}$ durumun su aktivitesini etkilediği düşünülmektedir. Ayvalara uygulanan ön işlemler örneklerin su aktivitesini artırmıştır. Ayva örneklerinin suda çözünen kuru madde değerleri incelendiğinde taze numunenin suda çözünen kuru madde değeri en düşük olup uygulanan işlemler suda çözünen kuru madde değerini artırmıştır. Ayva örneklerinin yă içeriği en yüksek ultrases ile birlikte düşük metoksil pektin kaplama uygulanıp infrared kurutulan uygulamada bulunmuştur. Düşük metoksil pektin kaplama ile kaplanan ayvaların yağ içeriği daha yüksek bulunmuştur. Kaplama işleminin yağ emilimi üzerinde etkisinden bahsetmek mümkündür. Literatüre bakıldığında aljinat ile yapılan kaplamalarda yağ emiliminin artışına yönelik bilgiler mevcuttur.

Sonuçlar incelendiğinde toplam fenolik bileşik ve antioksidan aktivite değerleri birbirine oldukça yakın olduğu gözlenmiştir. Ön işlem uygulaması yapılmadan infrared kurutulan ayvaların toplam fenolik bileşik miktarı en yüksek bulunmuştur. Infrared kurutma işlemi örneklerin fenolik bileşiklerini koruduğu söylenebilir. Düşük metoksil pektin kaplama uygulaması örneklerin fenolik bileşik kaybını azaltmıştır. Ayva örneklerinin atioksidan aktivitesi incelendiğinde infrared sistemde kurutulan örneklerin antioksidan kapasitelerinin arttığı gözlenmiştir. Düşük metoksil pektin kaplama uygulaması ayva örneklerinin antioksidatif bileşiklerin yapıda korunmasını sağlamıştır. Etüvde kurutma işlemi ile ayvaların flavanoid bileşiklerinde kayıpların olduğu tespit edilmiştir. Infrared sistemde kurutulan örneklerin flavanoid bileşikleri korunarak ultrases ön işlemi uygulaması yapıldığında e-ISSN: 2148-2683 edilmiştir $(\mathrm{p}<0.05)$. Düşük metoksil pektin ve sodyum aljinat kaplama uygulamaları ayvanın sarı renginin korunmasını sağlamıştır.

Sertlik (hardness, N) gıda numunesini sıkıştırmak için harcanan maksimum kuvvettir. Ayva örneklerinin sertlik özellikleri tekstür analizi ile incelenmiştir. Ultrases ön işleminin meydana getirdiği etki ayvaların sertlik değeri üzerine istatiksel olarak anlamlı bir farklılık oluşturmuştur $(\mathrm{p}<0,05)$. Ultrases ön işlemi uygulaması yapılarak infrared kurutulan üründe ultrases işleminin ayvaların sertlik değerini etkileyerek bir düşüşe sebep olduğu gözlenmektedir. Ultrases işlemi ayvaların kurutulmasında ürünün fazla sertleşmesini önleyebilen bir ön işlem olduğunun göstergesidir. Düşük metoksil pektin kaplama istatiksel bir artış sağlamıştır $(p<0,05)$. Sodyum aljinat ve düşük metoksil pektin kaplama uygulanıp infrared kurutulan örneklerin sertlik değeri kaplama materyali uygulamasından kaynaklanmaktadır. Kaplama materyallerinden sodyum aljinat kaplamanın ayvanın tekstürel özelliklerini daha fazla etkilediği söylenebilmektedir.

toplam flavanoid içeriğinde istatiksel olarak bir artış gözlenmiştir $(\mathrm{p}<0,05)$.

Ayvaların kurutulduğu bu çalışmada en fazla su kaybı etüvde kurutulan örneklerde tespit edilmiş ve bu numunelerde en düşük $L^{*}$ değeri gözlenmiştir. Nem değerindeki artış ile L değerindeki düşüş arasında bir ilişki kurulabilir. Infrared kurutma işleminde L değerinde artış meydana gelmiştir. L değerinde görülen artış esmerleşme reaksiyonlarının azaldığının göstergesidir. Bu durum esmerleşme reaksiyonlarına sebep olan polifenol oksidaz enziminin aktivitesinin infrared kurutma ile kurutulan örneklerde düştüğünün belirtisidir. Etüvde kurutulan ayvaların a* değerinde düşüş gözlenmiş olup renkte bir koyulaşma tespit edilmiştir. Infrared kurutma işlemi ile b* değerinde bir artış gözlenmiş olup örneklerde sarı rengin korunduğu tespit edilmiştir. Örneklerin sertlik değerinin etüv ve infrared kurutma yöntemlerinden etkilendiği gözlenmiştir. Etüv kurutmada görülen kurutma süresi artışının, ürün sertlik değeri üzerinde artırıcı etkisi olduğu tespit edilmiştir. Kurutma işleminde daha çok su kaybeden örneklerin sertlik değerinin daha yüksek olduğu gözlenmiştir. Çalışmalar infrared sistemde kurutma işleminin ayva örneklerinin aşırı sertleşmesini önleyen bir yöntem olduğunu göstermiştir.

Infrared kurutma uygulanan ayvaların $\mathrm{pH}$ değeri, toplam çözünür katı madde, titre edilebilir asitlik, toplam antioksidan aktivite, toplam fenolik içeriği ve toplam flavonoid içeriği sodyum aljinat ve düşük metoksil pektin kaplama materyalleri kullanılarak yenilebilir kaplama uygulamasıyla korunmuştur. $\mathrm{Bu}$ araştırma, ultrases ile birlikte düşük metoksil pektin kaplama ve ultrases ile birlikte sodyum aljinat kaplama ön işleminin infrared kurutulmuş ayva üretiminde etkili bir işlem olabileceğini düşündürmektedir. Sonuç olarak, ayva meyvesinin antioksidan aktivite, toplam fenolik bileşik, toplam flavanoid ve tekstürel özelliklerini korumak için sodyum aljinat ve düşük metoksil pektin kaplamaların yenilebilir kaplamalar olarak kullanılabileceği önerilebilir.

\section{Teșekkür}

$\mathrm{Bu}$ çalışmadaki yardım ve desteklerinden dolayı Erciyes Üniversitesi personeline ve yönetimine içtenlikle teşekkür ederim. 


\section{Kaynakça}

[1] Cemeroğlu, B., Yemenicioğlu, A., Özkan, M., 2009. Meyve ve sebzelerin bileşimi. Meyve sebze işleme teknolojisi Cilt 1. Gida Teknolojisi Derneği Yayınları, Ankara.

[2] Pico, Y., 2012. Low-intensity ultrasounds. Chemical Analysis of Food: Techniques and Applications: Techniques and Applications, 117.

[3] Özkoç, S.Ö., 2010. Kızılötesi ve kızı̈ötesi-kombinasyon ısıtma teknolojilerinin gida işleme uygulamalarında kullanımı. Gıda, 35.3: 211-218.

[4] Safi, S., Morshed, M., Ravandi, H. S. A. and Ghiachi, M., 2007. Study of electrospinning of sodium alginate, blended solutions of sodium alginate/poly (vinyl alcohol) and sodium alginate/poly (ethylene oxide). J. of App. Polym. Sci.; 104, 5, 3245-3255.

[5] Khin, Mya Mya; Zhou, Weibiao; Perera, Conrad O, 2006. A study of the mass transfer in osmotic dehydration of coated potato cubes. Journal of Food Engineering, 77.1: 84-95.

[6] Topdaş EF, Başlar M, Ertugay MF., 2011. "Elmaların ozmotik kurutulması üzerine ultrases işleminin etkisi". Akademik Glda, 9(5), 6-10.

[7] Özaydın, A.G., 2013. Farklı kurutma koşullarının bazı önemli armut çeşitlerinin aroma, fenolik madde ve diğer kalite bileşenleri üzerine etkilerinin araştırılması. $\mathrm{PhD}$ Thesis. Süleyman Demirel Üniversitesi Fen Bilimleri Enstitüsü.

[8] Güven, A., 2016. Elma, ayva ve muz meyvelerine uygulanan ozmotik dehidrasyon ön-işleminin bu meyvelerin kalite parametreleri üzerine etkisi ve kinetik modellemesi.

[9] Cemeroğlu, B., 1992. Meyve ve Sebze İşleme Endüstrisinde Temel Analiz Metotları. Biltav Yayınları, Ankara. 381 s.

[10]Yokuş, B., 2014. Farklı ön işlemlerin ve uygulanan farklı kurutma yöntemlerinin elmada toplam fenol miktarı ve antioksidan aktivite üzerine etkileri, Bilecik Şeyh Edebali Üniversitesi Fen Bilimleri Enstitüsü Yüksek Lisans Tezi. Bilecik.

[11]Marston, K., Khouryieh, H., Aramouni, F., 2016. Effect of heat treatment of sorghum flour on the functional properties of gluten-free bread and cake. Food Science and Technology, (65): 637-644.

[12]Koiwai, H., \& Masuzawa, N., 2007. Extraction of catechins from green tea using ultrasound. Japanese Journal of Applied Physics, 46(7S), 4936.

[13]Vilkhu, K., Mawson, R., Simons, L., \& Bates, D., 2008. Applications and opportunities for ultrasound assisted extraction in the food industry-A review.Innovative Food Science \& Emerging Technologies, 9(2), 161-169. 